\title{
PATTERN OF FATAL CHEST INJURY DUE TO ROAD TRAFFIC ACCIDENTS IN BIHAR STATE
}

\author{
Deepmalaํ, Vibhuti Bhushan², Sanjeev Kumar³, Binay Kumar ${ }^{4}$, Arbind Kumar Singh ${ }^{5}$, Mukti Nath Singh ${ }^{6}$, Binod Kumar Ravi ${ }^{7}$
}

${ }^{1}$ Senior Resident, Department of Forensic Medicine \& Toxicology, AIIMS, Patna.

${ }^{2}$ Associate Professor, Department of General Surgery, IGIMS, Patna.

${ }^{3}$ Additional Professor, Department of Anaesthesiology \& Critical Care Medicine, IGIMS, Patna.

${ }^{4}$ Assistant Professor \& Incharge Head, Department of Forensic Medicine \& Toxicology, AIIMS, Patna.

${ }^{5}$ Associate Professor, Department of Forensic Medicine \& Toxicology, NMCH, Patna.

${ }_{6}^{6}$ Professor and Head, Department of Forensic Medicine \& Toxicology, NMCH, Patna.

${ }^{7}$ Senior Resident, Department of Forensic Medicine \& Toxicology, AIIMS, Patna.

\begin{abstract}
Bihar is relatively a backward state of India where deaths due to chest injuries in road traffic accidents are very common. Deaths due to chest injuries could be more preventable and treatable than head injuries due to road traffic accidents.

\section{OBJECTIVE}

The main objective of our study is to give emphasis on various aspect of deaths due to chest trauma in road traffic accidents, so that policies could be made by lawmakers to prevent these deaths and also to enrich the knowledge of clinicians about various reasons of death of traffic chest trauma victims.
\end{abstract}

\section{MATERIAL AND METHOD}

This is a prospective study, consists of 201 fatal chest trauma cases due to road traffic accident, brought for medico-legal autopsies to the mortuary of NMCH, Patna, between August 2011 and July 2013. The data were analysed in tabular form and percentage method.

\section{RESULTS}

The study revealed that most of the traffic fatal chest trauma cases were pedestrians (67.2\%), male (92\%) and were of productive age group of life (37\% between 31 and 45 years' age group). Majority of the accidents took place on highways (62.7\%) in winter season (29.35\%) and victims died on spot (72.5\%). Shock and Haemorrhage (84.5\%) was the most common cause of death, while fatal chest injuries generally combined with abdominal injuries (51.3\%) also. Liver (50\%) and Spleen (28.3\%) were also injured in some victims. Contusions (42.7\%), Rib fracture (61.2\%) and Haemothorax (89\%) were the other common findings in fatal chest trauma victims due to Road Traffic Accident (RTA).

\section{CONCLUSIONS}

On the basis of this study, we can highlight various aspects of deaths due to chest trauma in road traffic accidents and accordingly the need to deploy the "Quick response teams" on highways and "Hi-Tech Trauma Centre" at district head-quarters can be justified to reduce the mortality in such cases.

\section{KEYWORDS}

Chest Injuries, Fatal, Road Traffic Accidents.

HOW TO CITE THIS ARTICLE: Deepmala, Bhushan V, Kumar S, et al. Pattern of fatal chest injury due to road traffic accidents in Bihar state. J. Evolution Med. Dent. Sci. 2016;5(41):2494-2497, DOI: 10.14260/jemds/2016/582

\section{INTRODUCTION}

Road Traffic Accident is like an endemic disease, which affects mainly young people. Currently, motor vehicle accidents rank ninth in order of disease burden and are projected to be ranked third by 2020.[1] The fatality rate in road traffic accidents in India is one of the highest in world and reported to be twenty times more than that reported in the developed countries. The increasing number of fast moving vehicle, bad roads, pedestrian lacking road sense, factory accidents, incidence of violence and personal enmity with increase of lawlessness leads to injuries and unnatural death. ${ }^{[2]}$

Financial or Other, Competing Interest: None.

Submission 07-04-2016, Peer Review 30-04-2016,

Acceptance 07-05-2016, Published 20-05-2016.

Corresponding Author:

Dr. Deepmala,

D-4/2, IGIMS-Campus,

Sheikhpura,

Patna-800014

Bihar, India.

E-mail:drvibhuti.bhusan@gmail.com

DOI: $10.14260 /$ jemds $/ 2016 / 582$
Lungs and heart are two major organs inside chest cavity. It means among the three pods of life (Tripod), two pods are present in this cavity.[3] The cause responsible for injuries during RTA are usually physical factor like collision between victims and the external environment and acceleration or deceleration forces acting on victim's internal organs.

A punctured wound of lung and pleurae may result in infection and delayed death from bronchopneumonia or empyema. In closed type of wound, the common injuries of lung are contusions and lacerations. Fatality in chest trauma cases are due to deranged cardiorespiratory function, uncontrolled bleeding, associated injuries and sepsis. The incidence of thoracic trauma was $46 \%$. Patient with thoracic injuries had a mortality rate of $15.7 \%$, while those without thoracic injuries had a mortality rate of $12.8 \% .[4,5]$

Despite significant social impact of traumatic death, very few reliable epidemiological data are available of fatal chest injury due to RTA. This study was undertaken to access the pattern of chest injuries in fatal road traffic accidents around Patna, a relatively backward area of India. 


\section{MATERIAL AND METHOD}

The present study comprised of 201 cases of fatal chest injury due to RTA brought to the mortuary of Department of Forensic Medicine and Toxicology, Nalanda Medical College Hospital, Patna, from August 2011 to July 2013 for medico-legal autopsies. Details of deceased were noted from inquest report and relatives whenever possible. Various epidemiological data, external and internal injuries were noted and analysed.

\section{Exclusive Criteria}

Those cases where bodies were decomposed and where natures of injuries not known are not included.

\section{RESULTS}

The study was conducted during period of August 2011 to July 2013 of cases brought for medico-legal autopsies at NMCH, Patna with fatal chest trauma due to road traffic accidents.

\begin{tabular}{|c|c|c|}
\hline $\begin{array}{c}\text { Different } \\
\text { Months }\end{array}$ & $\begin{array}{c}\text { No. of } \\
\text { Death }\end{array}$ & $\begin{array}{c}\text { Percentage } \\
\text { (\%) }\end{array}$ \\
\hline $\begin{array}{c}\text { Winter } \\
\text { (December to February) }\end{array}$ & 59 & 29.3 \\
\hline Summer (March to May) & 45 & 22.4 \\
\hline $\begin{array}{c}\text { Rainy season } \\
\text { (June to August) }\end{array}$ & 50 & 24.9 \\
\hline $\begin{array}{c}\text { Autumn } \\
\text { (September to November) }\end{array}$ & 47 & 23.4 \\
\hline $\begin{array}{c}\text { Table 1: Seasonal Variations of Fatal } \\
\text { Chest Injury due to RTA }\end{array}$ \\
\hline
\end{tabular}

\begin{tabular}{|c|c|c|c|}
\hline Age & $\begin{array}{c}\text { Male } \\
\text { (\% in Males) }\end{array}$ & $\begin{array}{c}\text { Female } \\
\text { (\% in } \\
\text { Females) }\end{array}$ & $\begin{array}{c}\text { Total No. of } \\
\text { Victims }\end{array}$ \\
\hline $0-15$ & $9(4.8 \%)$ & $2(12.5 \%)$ & $11(6.25 \%)$ \\
\hline $16-30$ & $61(32.9 \%)$ & $4(25 \%)$ & $65(12.5 \%)$ \\
\hline $31-45$ & $71(38.3 \%)$ & $3(18.7 \%)$ & $74(37 \%)$ \\
\hline $45-60$ & $36(19.4 \%)$ & $7(43.7 \%)$ & $43(21.5 \%)$ \\
\hline$>60$ & $8(4.3 \%)$ & $0(0 \%)$ & $8(4 \%)$ \\
\hline Total & $\mathbf{1 8 5}(\mathbf{9 2 \% )}$ & $\mathbf{1 6}(\mathbf{8} \%)$ & $\mathbf{2 0 1}$ \\
\hline \multicolumn{4}{|c|}{ Table 2: Age \& Sex Distribution } \\
\hline
\end{tabular}

\begin{tabular}{|c|c|}
\hline Types of Victims & No. \& Percentage of Victims \\
\hline Pedestrian & $135(67.2 \%)$ \\
\hline Cyclists & $1(0.5 \%)$ \\
\hline Motorcyclists & $4(2 \%)$ \\
\hline Car & $4(2 \%)$ \\
\hline Passengers & $24(12 \%)$ \\
\hline Unknown & $33(16.5 \%)$ \\
\hline Table 3: Types of Victims of Traffic Fatal Chest Trauma \\
\hline
\end{tabular}

\begin{tabular}{|c|c|}
\hline Types of Road & No. \& Percentage of Victims \\
\hline City Roads & $27(13.5 \%)$ \\
\hline Highways & $126(62.7 \%)$ \\
\hline Not Known & $48(23.8 \%)$ \\
\hline \multicolumn{2}{|c|}{ Table 4: Types of Road in Accidents } \\
\hline
\end{tabular}

\begin{tabular}{|c|c|}
\hline Period of Survival & No. \& Percentage of Victims \\
\hline Spot death & $137(68 \%)$ \\
\hline Death within 24 hours & $47(23.5 \%)$ \\
\hline Death after 24 hours & $9(4.5 \%)$ \\
\hline Not Known & $8(4 \%)$ \\
\hline $\begin{array}{c}\text { Table 5: Period of Survival of Victims } \\
\text { of Fatal Chest Injury due to } \text { RTA }\end{array}$ \\
\hline
\end{tabular}

\begin{tabular}{|c|c|}
\hline $\begin{array}{c}\text { Body Parts } \\
\text { Involved }\end{array}$ & $\begin{array}{c}\text { No. \& Percentage of } \\
\text { Victims }\end{array}$ \\
\hline Chest alone & $23(11.4 \%)$ \\
\hline $\begin{array}{c}\text { Chest with Head \& Neck } \\
\text { Injuries }\end{array}$ & $30(14.9 \%)$ \\
\hline $\begin{array}{c}\text { Chest and Abdominal } \\
\text { Injuries }\end{array}$ & $103(51.3 \%)$ \\
\hline \multicolumn{2}{|c|}{ Combined } \\
\hline $\begin{array}{c}\text { Table 6: Involved Body Parts of Victims } \\
\text { of Fatal Chest Injury due to RTA }\end{array}$ \\
\hline
\end{tabular}

\begin{tabular}{|c|c|}
\hline $\begin{array}{l}\text { Mode of } \\
\text { Death }\end{array}$ & $\begin{array}{l}\text { No. \& Percentage } \\
\text { of Victims }\end{array}$ \\
\hline Asphyxia & $12(6 \%)$ \\
\hline $\begin{array}{c}\text { Shock \& Haemorrhage with } \\
\text { Asphyxia }\end{array}$ & $14(7 \%)$ \\
\hline Shock \& Haemorrhage & $170(84.5 \%)$ \\
\hline Septicaemia & $5(2.5 \%)$ \\
\hline \multicolumn{2}{|c|}{$\begin{array}{l}\text { Table 7: Mode of Death in Victims } \\
\text { of Fatal Chest Injury due to RTA }\end{array}$} \\
\hline
\end{tabular}

\begin{tabular}{|c|c|}
\hline $\begin{array}{c}\text { Pattern of External } \\
\text { Thoracic Injuries }\end{array}$ & $\begin{array}{c}\text { No. \& Percentage } \\
\text { of Victims }\end{array}$ \\
\hline Contusion & $86(42.7 \%)$ \\
\hline Abrasion & $70(34.8 \%)$ \\
\hline Laceration & $12(6 \%)$ \\
\hline Incised Wound & $2(1 \%)$ \\
\hline No External Injury & $31(15.5 \%)$ \\
\hline $\begin{array}{c}\text { Table 8: Pattern of External Thoracic Injuries } \\
\text { in Victims of Fatal Chest Trauma due to RTA }\end{array}$ \\
\hline
\end{tabular}

\begin{tabular}{|c|c|}
\hline $\begin{array}{c}\text { Bony } \\
\text { Injuries }\end{array}$ & $\begin{array}{c}\text { No. \& Percentage } \\
\text { of Victims }\end{array}$ \\
\hline Ribs & $123(61.2 \%)$ \\
\hline Clavicle & $11(5.5 \%)$ \\
\hline Sternum & $8(4 \%)$ \\
\hline Combined & $59(29.3 \%)$ \\
\hline \multicolumn{2}{|c|}{ Table 9: Bony Injuries in Victims of } \\
Fatal Chest Injury due to RTA
\end{tabular}

\begin{tabular}{|c|c|}
\hline $\begin{array}{l}\text { Condition of } \\
\text { Pleural Cavity }\end{array}$ & $\begin{array}{l}\text { No. \& Percentage } \\
\text { of Victims }\end{array}$ \\
\hline Normal & $6(3 \%)$ \\
\hline Haemothorax & $179(89 \%)$ \\
\hline Pyothorax & $5(2.5 \%)$ \\
\hline Pneumo-thorax & $6(3 \%)$ \\
\hline Combined & $5(2.5 \%)$ \\
\hline \multicolumn{2}{|c|}{$\begin{array}{l}\text { Table 10: Condition of Pleural Cavity in } \\
\text { Victims of Fatal Chest Injury due to RTA }\end{array}$} \\
\hline
\end{tabular}

\begin{tabular}{|c|c|}
\hline $\begin{array}{l}\text { Organ Involved in the } \\
\text { Chest Cavity }\end{array}$ & $\begin{array}{c}\text { No. \& Percentage } \\
\text { of Victims }\end{array}$ \\
\hline Lung & $150(74.5 \%)$ \\
\hline Lung and Heart & $28(14 \%)$ \\
\hline $\begin{array}{c}\text { Combined (Heart, Lung, Great } \\
\text { Vessel, Lymphatics) }\end{array}$ & $11(5.5 \%)$ \\
\hline Normal & $12(6 \%)$ \\
\hline
\end{tabular}




\begin{tabular}{|c|c|}
\hline \multicolumn{2}{|c|}{ Victims of Fatal Chest Injury due to RTA } \\
\hline $\begin{array}{c}\text { Other Associated Abdominal } \\
\text { Organ Injuries }\end{array}$ & $\begin{array}{l}\text { No. \& Percentage of } \\
\text { Victims }\end{array}$ \\
\hline Liver & $100(50 \%)$ \\
\hline Spleen & $57(28.3 \%)$ \\
\hline Kidney & $19(10 \%)$ \\
\hline Stomach & $5(3 \%)$ \\
\hline Multi-organ injuries & $16(7.7 \%)$ \\
\hline $\begin{array}{r}\text { Table 12: Other Associated Abo } \\
\text { Victims of Fatal Chest }\end{array}$ & $\begin{array}{l}\text { nal Organ Injuries in } \\
\text { y due to RTA }\end{array}$ \\
\hline
\end{tabular}

Nearly 22\% (201 cases out of 903 total victims) of cases brought for medico-legal autopsy to the department were of fatal chest trauma due to RTA, while maximum no. of deaths occurred in winter season i.e. December to February (Table-1).

Maximum no. of death of victims of chest trauma occurred between age groups 31-45 years of age with male predominance (Table-2). Pedestrians were the most common affected victims (Table-3) and these accidents took place mostly in Highways (Table-4). Maximum no. of victims died on spot (68\%; 137 out of 201 cases); 47 victims (23.5\%) died within 24 hours, while 9 (4.5\%) victims survived beyond 24 hours (Table-5). Chest and Abdomen injuries and other combined injuries were more common injuries than isolated Chest injury in Traffic fatal chest trauma (Table-6).

Shock and Haemorrhage is more common mode of death in victims of traffic fatal chest trauma (Table-7). Either Contusion or Laceration were present on chest in these cases (Table-8). Rib fractures were the most common bony injuries in 123 victims (61\%) (Table-9), while Haemothorax was most common finding of pleural cavity of these victims (Table-10).

Lungs were injured in 150 (74.5\%) cases followed by Heart and Lung and Combined injuries (Table-11). Liver injuries were the other common abdominal organ injuries followed by splenic injuries in victims of fatal chest trauma due to RTA (Table-12).

\section{DISCUSSION}

Now a days, fatal road traffic accidents are among the leading cause of death and has not spared people of any age group, any region. In this study, fairly high ratios of death $(22.2 \%)$ were due to fatal traffic chest trauma, which is consistent with the finding of Singh B et al, Sharma RK et al,(6,7) Shetty BSK et al. It may often be due to fast moving vehicle, narrow roads and lack of road sense. Regarding seasonal variations, maximum no. of death were reported in winter season (Dec to Feb) followed by rainy season (June to August). These findings were comparable to study conducted by Singh YN et al, Marchant S $P$ et al and Archana Kaul D et al. $(8,9,10)$ It might be the low visibility on roads due to fog, increased no. of vehicle and migratory nature of people, mainly labours return to their home for harvesting purpose during these seasons.

Majority of victims were of age group 31-45 years (38.3\%) with male preponderance (11.5:1). These findings are comparable with the studies of Kumar PM et al and Shetty BSK et al(11) It may be due to the fact that these age groups are the main bread earners and also males spend most of the time in outdoor activities.

Pedestrians were most commonly affected group (67.1\%) and majority of accidents took place on highways. Majority of victims died on spot (72.5\%). These findings are comparable to the studies of Sharma RK et al, Kumar MP et al, Shetty BSK et al and Singh $\mathrm{H}$ et al.[7,11,12) These findings may be due to the fact that majority of pedestrians lack road and traffic sense, narrow roads, rash driving, etc. Deaths on spot could be minimized if "quick response teams," especially dedicated to trauma were available at regular intervals.

Abdomen were the commonly involved body part in addition to chest injury in victims of fatal chest trauma $(51.2 \%)$ due to RTA as in study of Shetty BSK et al, Oberoy SS et al.(11,13) Shock and Haemorrhage were the main cause of death $(84.5 \%)$ in these cases followed by Shock and Haemorrhage with Asphyxia. These findings are consistent with others and it may be due to high vascularity of lung and also majority of Great vessels passes through the thorax. Regarding pattern of external thoracic injuries, contusions $(42.7 \%)$ followed by abrasions $(34.8 \%)$ and lacerations $(6 \%)$ were observed. Regarding bony injuries, Rib fracture $(61.2 \%)$ followed by multiple fracture and clavicle fracture (5.5\%) were observed as in study of Pathak M et al, Shetty BSK et al, Oberoy SS et al.(11,13) These findings may be due to fact that pedestrians were most commonly affected group and internal thoracic organs became unprotected once rib cage become injured.

Majority of victims of traffic fatal chest injuries had haemothorax (89\%) followed by pneumothorax (3\%), pyothorax and combined (2.5\%). Majority had instant death (68\%) followed by death in hospital within 24 hours $(23.5 \%)$ and very few survived beyond 24 hours (4.5\%). These findings are also in consistent with studies of Singh B et al, Kumar PM et al, Veyesi TV et al.(6,14)

Further observations in our study showed that liver (49\%) was the most common injured organ followed by spleen $(28 \%)$ and combined injuries, which was also observed in the studies of Kumar PM et al, Bowley D et al.[15] These findings were may be due to anterior location of liver and spleen making susceptible to blunt injuries.

\section{CONCLUSION}

Fatal chest trauma due to road traffic accident has now become the chief cause of death affecting most active and most productive age group. Involvement of pedestrian in large number reflects lack of road sense and traffic rules and rash driving. Most death occurs on spot or within 24 hours, which suggests seriousness of injuries and require immediate, prompt and adequate medical help so that golden hour can be saved. There needs to be education programme and law enforcement with regards to traffic rules and road safety, especially during winter and summer holidays. Further "HiTech Trauma Centre" at every district head-quarter and on highway at different interval is the present need to reduce the mortality.

\section{REFERENCES}

1. The World Health Report 1995, Report of the Director General WHO. Accessed on 21/12/14, 1995.

2. Hogarth J. Glossary of health care terminology WHO, Copenhagen, Accessed on 21/12/14, 1978.

3. Iyer RS, Manoj P, Jain R, et al. Profile of chest trauma in a referral hospital: a five year experience. Asian Cardiovasc Thorac Ann 1999;7(2):124-7.

4. Hill AB, Fleiszer DM, Brown RA. Chest trauma in Canadian urban setting-implication for trauma research in Canada. J Trauma 1991;31(7):971-3. 
5. Devit JH, McLean RF, Koch JP. Anaesthetic management of blunt thoracic trauma. Can J Anaesth 1991;38(4):50610.

6. Singh B, Palimar V, Arun M, et al. Profile of trauma related mortality at Manipal. Kathmandu Univ Med J (KUMJ) 2008;6(23):293-7.

7. Sharma RK. Pattern of chest injuries in road traffic accidents. Souvenir 12th Annual Conference of Indian Academy of Forensic Med 1990;p 33.

8. Singh YN, Bairagi K, Das KC. An epidemiological study of road traffic accident victims in medico-legal autopsies. JIAFM 2005;27(3):166-9.

9. Marchant SP, Rohit ZC, Tapan M, et al. Epidemiology of road traffic accident (RTA) victims in Ahmedabad-a study of 5 years (1995-1999). JIAFMS 2009;31(1):37-42.

10. Archana Kaul, Sinha US, Kapoor AK, et al. An epidemiological study of fatal road traffic accidents in Allahabad region. IIJFMT 2005;3(1).
11. Shetty SK, Kanchan T, Menezes RG, et al. Victim profile and pattern of thoraco-abdominal injuries sustained in fatal road traffic accidents. J Indian Acad Forensic Med 2012;34(1):16-9.

12. Singh H, Dhattarwal SK, Mittal S, et al. A review of pedestrian traffic fatalities. JIAFM 2007;29(4):55-7.

13. Oberoi SS, Sandhu HS, Aggarwal KK, et al. Pattern and distribution of injuries in fatal two wheeler accidental cases. J Panjab Acad Forensic Med Toxicol 2011;11(1):31-3.

14. Veyesi TV, Vassilios S Nikolaou, Christos Paliobeis, et al. Prevalence of chest trauma, associated injuries and mortality: a level trauma centre experience. Int Orthop 2009;33(5):1425-33.

15. Pathak MK, Ziya A, Prashant A, et al. Fatality due to chest injury in road traffic accident victims of Varanasi and adjoining districts, U.P. Medico Update 2006;6(3):7-9. 